\title{
Effects of combined nutrient supply treatments on some physiological parameters of autumn wheat
}

\author{
TÜNDE KAPRINYÁK ${ }^{1}$ - RÉKA LÁPOSI ${ }^{1}$ - LÁSZLÓ BEKŐ ${ }^{2}$ - SZILÁRD TÓTH ${ }^{3}$ \\ Eszterházy Károly University \\ ${ }^{1}$ Institute of Agricultural Sciences and Environmental Management, \\ Gyöngyös, Hungary \\ ${ }^{2}$ Remote Sensing and Rural Development Research Institute, \\ Gyöngyös, Hungary \\ ${ }^{3}$ Fleischmann Rudolf Agricultural Research Institute, \\ Kompolt, Hungary \\ kaprinyak.tunde@uni-eszterhazy.hu
}

\begin{abstract}
Summary
The Fleischmann Rudolf Research Institute in Kompolt is not only famous for plant breeding but the institute also surveys the effects of different nutrient supply methods since 1918. In 2017, we joined this research supported by EFOP 3.6.1 project. Our aim was to investigate photochemical processes - which is one of the most determinant in case of yield - of crops by in vivo field measurements. We measured the chlorophyll content of leaves using Minolta SPAD 502. We used miniPAM fluorometer to determine actual photochemical efficiency and non-photochemical quenching of PSII during natural light conditions and also to evaluate the pigment (chlorophylls and carotenoids) and water content of leaves we applied field spectrophotometer (ASD FieldSpecPro 3). We utilized these methods by various treatments (1. treatment with soil bacteria + head and base fertilizer; 2 . treated by only head fertilizer; 3 . treated by only base-fertilizer) in field experiment of autumn wheat (4.1-2.43-1.19 ha) in June, 2017. The difference between treatments was clearly detectable. In the case of the first treatment, physiological processes were more intense and the ripening occurred earlier. The obtained yield was the highest in the case of the area treated by soil bacterial. Based on the results, the first treatment can be recommended in practice.
\end{abstract}

Keywords: autumn wheat, crop safety, in vivo measurements, soil bacteria

\section{Introduction}

In the Fleischmann Rudolf Research Institute investigation the effects of various nutrition supply systems has been outmost importance for nearly 100 years. In 2017 we joined these experiments in order to monitor the photochemical processes of plants by in vivo field measurements, which can influence the quantity and quality of yield. Among our arable crops, autumn wheat has paramount importance for both food and feed purposes. Due to the excellent ecological conditions of the Carpathian 
Basin, Hungary is a major wheat-making country. According to FAO data (Net1), the world's wheat production area exceeds 220 million hectares, from it, Hungary represents approximately $0.5 \%$. All harvested crops have grown since 1990; in 2016 it was 740 million tons. In Hungary, however, it shows a downward trend. In 1990 it still exceeded 6 million $t$, but in 2016 it did not reach already 4.8 million $t$. The CSO (Net2) also reported lower values, but in a smaller area (1.044 thousand hectares) a larger quantity (5603 thousand tons) was aggregated. However, the domestic average yield is still increasing. In 2014, $4.7 \mathrm{t} \mathrm{ha}^{-1}$ and in 2016 $5.37 \mathrm{t} \mathrm{ha}^{-1}$ wheat were recorded in register of the CSO. This is most likely due to technological development as well as the increasing amount of fertilizer used. The fertilizer per hectare of agricultural land in 2000 was $61 \mathrm{~kg}$; by 2016 it rose to $103 \mathrm{~kg}$. Monoculture cultivation and increasing amounts of fertilizer use are increasingly burdening the environment. However, farmers are forced to increase agricultural production during climate change conditions and demographic explosion of developing countries. The goal is to produce a larger quantity in a smaller area. An important element of sustainable agriculture is the preservation of soil fertility. Crop security is a key issue for achieving successful agriculture in the long term. To achieve this, the use of soil bacteria will help. Several similar products have appeared on the market over the last years.

\section{Materials and methods}

\section{Properties of the experimental area}

The experiment was carried out at the Fleischmann Rudolf Research Institute in Kompolt, which is located in the southern part of the southern mountain range of Mátra between Eger and Gyöngyös, an average of 125 meters above sea level. Its weather is extreme, especially during the summer period, with few precipitation (Holló et al., 2009ab). In 2017, the annual precipitation amounted to $529.8 \mathrm{~mm}$, from which rainfall reached $418.3 \mathrm{~mm}$ in summer. The average number of sunny hours is 2108, and 1528 hours in the vegetation period. The average annual temperature was $10{ }^{\circ} \mathrm{C}$, which was $10.67{ }^{\circ} \mathrm{C}$ in 2017. Over the vegetation period, in multiannual average of $17.3^{\circ} \mathrm{C}$ (Herczeg, 2013), while in 2017 the average temperature was $17.05{ }^{\circ} \mathrm{C}$ according to local meteorological station data. In the area of the research institute, chernozem brown forest soil is the main soil type, the thickness of the humus layer is between 0.5 and $0.8 \mathrm{~m}$ (Holló and Kádár, 2003). Based on the latest soil analysis (Table 1) the area can be characterized by poor phosphorus content, with sufficient potassium content and low humus content. 
Table 1. Soil parameters of the experimental area (Károly Róbert College, Fleischmann Rudolf Research Institute, 2015)

\begin{tabular}{|c|c|c|c|c|c|c|c|}
\hline $\begin{array}{c}\text { Sample } \\
\text { depth } \\
(\mathrm{cm})\end{array}$ & $\begin{array}{c}\mathrm{pH} \\
(\mathrm{KCl})\end{array}$ & $\begin{array}{l}\text { Gold's } \\
\text { binding }\end{array}$ & $\begin{array}{l}\text { Soluble } \\
\text { salt in } \\
\text { water } \% \\
(\mathrm{~m} / \mathrm{m})\end{array}$ & $\begin{array}{l}\text { Humus } \\
\text { content \% } \\
(\mathrm{m} / \mathrm{m})\end{array}$ & $\begin{array}{c}\text { Soluble } \\
\text { potassium } \\
(\mathrm{AL}) \text { in } \mathrm{K}_{2} \mathrm{O} \\
\mathrm{mg} / \mathrm{kg}\end{array}$ & $\begin{array}{c}\text { Soluble } \\
\text { phosphorus } \\
(\mathrm{AL}) \text { in } \mathrm{P}_{2} \mathrm{O}_{5} \\
\mathrm{mg} / \mathrm{kg}\end{array}$ & $\begin{array}{c}\text { Soluble } \\
\left(\mathrm{NO}_{2}+\mathrm{NO}_{3}\right)-\mathrm{N} \\
(\mathrm{KCl}) \\
\mathrm{mg} / \mathrm{kg}\end{array}$ \\
\hline $0-30$ & 4.47 & 43 & 0.07 & 2.1 & 227 & 123 & 18 \\
\hline
\end{tabular}

\section{Experiment features}

Preparation of experiment

In the year 2016, the forecrop was an autumn cabbage rape. The basic fertilizer NPK=8:24:24; a total of $174.96 \mathrm{~kg} \mathrm{ha}^{-1}$ was on the total area. The soil bacteria treatment on 4.1 ha was $1 \mathrm{l} \mathrm{ha}^{-1}$ with a spraying machine (Gambetti in 1000 liters of water). Sowing time was on $23^{\text {rd }}$ of November in 2016. Ortegus variety of autumn wheat was selected, of which $250 \mathrm{~kg}$ ha $^{-1}$ seed was needed. On 2nd of February in $201796.15 \mathrm{~kg} \mathrm{ha}^{-1}$ head fertilizer and $27 \%$ Péti salt were applied. Dispensing of the head fertilizer was carried out in case of soil bacteria treated 4.1 ha and in case of 2.43 ha without soil bacteria (control with head and basic fertilizer). The remained 1.19 ha only received basic fertilizer. The 1.19 ha without head fertilizer only received basic fertilizer (control with only basic fertilizer). The experiment was set up in 4 repetitions in the following ways:

- With soil bacteria: $10250 \mathrm{~m}^{2}$ per repeat;

- With head and basic fertilizer: $5350 \mathrm{~m}^{2}$ per repeat;

- With basic fertilizer: $2975 \mathrm{~m}^{2}$ per repeat.

The applied soil microbe product contains free-living, nitrogenbinding and phosphor-mobilization soil-dwelling bacteria (50\% Pseudomonas, 25\% Azotobacter és 25\% Azospirillum strains) and microelements (Dilci, 2008; Szabados, 2008; Net3). The preparation does not contain any chemicals or hormones, its soil improver effect can reduce the amount of fertilizer applied (Net3). The seemingly costly treatment of bacterial preparations is suitable to reduce the adverse effects of climate change, thus achieving better quality and more crops. (Kátai, 2011; Net4).

Their use helps to create and maintain healthy, equilibrium soil life. They have already been supported by Agri-environment schemes (AES) (Net5). The beneficial effect can be solved only by living soil bacteria; therefore it is indispensable to stay alive until they are incorporated into the soil. The product has to be protected from light and high temperature until use (Net3; Net6). 


\section{Methods of measurements}

We investigated some photochemical parameters using in vivo chlorophyll fluorescence induction method with miniPAM fluorometer (WALZ GmbH, Germany) under unclouded natural light conditions

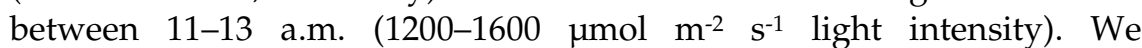
determined the actual photochemical efficiency of the PSII system $\left(\Delta \mathrm{F} / \mathrm{F}_{\mathrm{m}}{ }^{\prime}=\mathrm{F}_{\mathrm{m}}{ }^{\prime}-\mathrm{F} / \mathrm{F}_{\mathrm{m}}{ }^{\prime}\right.$; Genty et al., 1989$)$ and the rate of electron transport $\left(\mathrm{ETR}=\left(\Delta \mathrm{F} / \mathrm{F}_{\mathrm{m}}{ }^{\prime} \times \mathrm{PAR} \times 0.5 \times 0.84\right)\right.$ and the ratio of photochemical $\left(\mathrm{qP}=\mathrm{F}_{\mathrm{m}}{ }^{\prime}-\right.$ $\left.\mathrm{F} / \mathrm{F}_{\mathrm{m}}{ }^{\prime}-\mathrm{F}_{0}\right)$ and non-photochemical processes $\left(\mathrm{qN}=\mathrm{F}_{\mathrm{m}}-\mathrm{F}_{\mathrm{m}}{ }^{\prime} / \mathrm{F}_{\mathrm{m}}-\mathrm{F}_{0}\right.$, where $\mathrm{F}_{\mathrm{m}}$ - maximum fluorescence, $\mathrm{F}_{0}$ - basic fluorescence) (Net7; Schreiber et al., 1998). The relative chlorophyll content was measured by the Minolta SPAD 502 automatic meter. The device measures at the red light, since absorption of this is not affected by the contents of the leaf carotene (Markwell, 1995; Hawkins et al., 2009). The second leaves of the plants were measured in the upper third. For each plant 2 measurements were made to reduce measurement errors, it means 80 measurements per plot. The measurements were executed on 19th of June in 2017, at the advanced maturation stage. We carried out spectroscopic reflectance measurements by ASD FieldSpec3 portable spectroradiometer (USA) and determined vegetation indices (NDVI, RDVI, EVI, TCARI/OSAVI, SIPI, PRI, ARI, CRI, PWI, SRWI)) from which chlorophyll, carotenoid and water content of the leaves can be calculated. The method is used to isolate the reflection properties of plants (Spinetti et al., 2009).

During the vegetation period (2016-06) the following parameters were recorded with remote sensing methods:

- Structural indices

Normalized Difference Vegetation Index (mean spectra):

$\mathrm{NDVI}=\left(\mathrm{R}_{\mathrm{NIR}}-\mathrm{R}_{\mathrm{red}}\right) /\left(\mathrm{R}_{\mathrm{NIR}}+\mathrm{R}_{\mathrm{red}}\right)$ (Rouse et al., 1974),

Renormalized Difference Vegetation:

$\mathrm{RDVI}=\left(\mathrm{R}_{800}-\mathrm{R}_{670}\right) / \sqrt{ }\left(\mathrm{R}_{800}+\mathrm{R}_{670}\right)$ (Rougean and Breon, 1995);

- Leafindices

Structure Insensitive Pigment Index:

$\mathrm{SIPI}=\left(\mathrm{R}_{800}-\mathrm{R}_{450}\right) /\left(\mathrm{R}_{800}+\mathrm{R}_{650}\right)$ (Peñuelas et al., 1995),

Carotenoid Reflectance Index:

CRI=1/B550-1/B 700 (Gitelson et al., 2002),

Anthocyanin Reflectance Index:

$\mathrm{ARI}=\mathrm{B}_{840} \times\left(1 / \mathrm{B}_{550}-1 / \mathrm{B}_{700}\right)$ (Gitelson et al., 2001),

Optimized Soil-Adjust Vegetation Index:

OSAVI $=(1+0.16)^{*}\left(\mathrm{R}_{800}-\mathrm{R}_{670}\right) /\left(\mathrm{R}_{800}+\mathrm{R}_{670}+0.16\right)$ (Rondeaux et al., 1996),

Enhanced Vegetation Index

$(E V I)=2.5 \times\left(B_{840}-B_{670}\right) /\left(B_{840}+\left(6 \times B_{670}\right)-\left(7.5 \times B_{450}\right)+1\right)($ Huete et al., 2002); 
- Light utilization

Photochemical Reflectance Index:

$\mathrm{PRI}_{1}=\left(\mathrm{R}_{528}-\mathrm{R}_{567}\right) /\left(\mathrm{R}_{528}+\mathrm{R}_{567}\right)$,

$\mathrm{PRI}_{2}=\left(\mathrm{R}_{531}-\mathrm{R}_{570}\right) /\left(\mathrm{R}_{531}+\mathrm{R}_{570}\right)$,

$\mathrm{PRI}_{3}=\left(\mathrm{R}_{570}-\mathrm{R}_{539}\right) /\left(\mathrm{R}_{570}+\mathrm{R}_{539}\right)$ (Gamon et al., 1992);

- Water content

Plant Water Index:

PWI $=R_{970} / R_{900}$ (Peñuelas et al., 1997),

SRWI (Simple Ratio Water Index): $R_{858} / R_{1240}$ (Zarco-Tejada et. al., 2003).

We recorded at harvesting (22. 07. 2017) the yields $(\mathrm{t} \mathrm{ha-1})$ and the grain moisture (\%) values.

NDVI, RDVI vegetation indices were also determined by aerial photographs, which on a rigid, unmanned aerial vehicle (UAV) fixed 4channel multispectral camera system were made. After photogrammetric processing was the mosaic recording geometric resolution is $16 \mathrm{~cm}$.

Channel distribution of the multispectral camera system: green: 530$570 \mathrm{~nm}$; red: $640-680 \mathrm{~nm}$; red edge: $730-740 \mathrm{~nm}$; nearly infrared: $770-810$ nm.

During the vegetation period, soil samples were taken, soil samples at depths $0-20$ and $20-40 \mathrm{~cm}$. Soil parameters were determined in the laboratory and the contents of the macro-, meso- and micro element of the soil, plant. The latter were also analyzed from stored crops.

Evaluation of differences between measured parameters in case of different treatments was performed using SPSS 20 statistical program, One-Way ANOVA method.

\section{Results}

As shown in Figure 1, at all parameters were high the deviation, this has significantly influenced the result. The control had the highest relative chlorophyll content. However, its photosynthesis activity was also outstanding. However, for the three parcels, the light intensity was not the same. When evaluating the sunscreen mechanism of the plant, higher photochemical efficiency $\left(\Delta \mathrm{F} / \mathrm{Fm}^{2}\right)$ and lower non-photochemical photochemical extinction $(\mathrm{qN})$ were measured at the control. The electron transport rate (ETR), which is calculated by the instrument based on $\Delta \mathrm{F} / \mathrm{Fm}$ 'and the actual light intensity significantly was different for the three parcels, the control was higher.

It is apparent from the data in Table 2 that, like the SPAD value, the second treatment had lower the NDVI index, while the TCARI/OSAVI index was the lowest for treatment I. 
Figure 1. Relative chlorophyll content (SPAD value), photochemical activity ( $\left.\triangle F / F m^{\prime}\right)$, electron transport rate (ETR), non-photochemical quenching of PSII ( $q N)$ of autumn wheat (Kompolt, 19/06/2017)

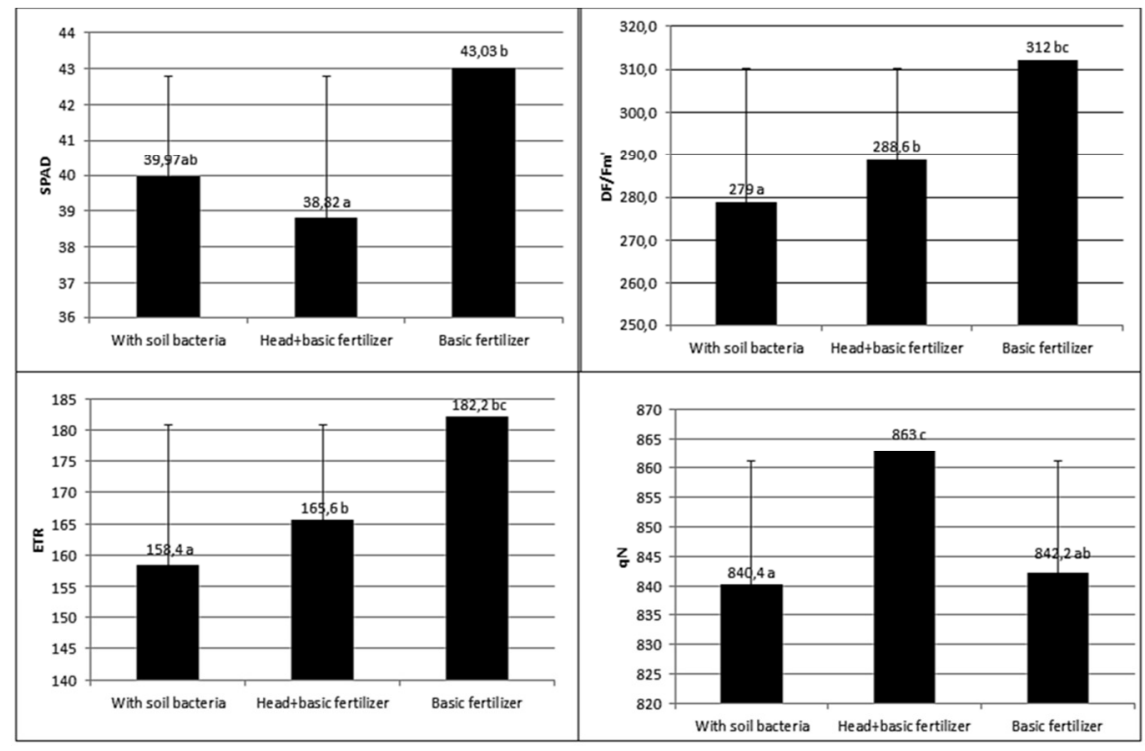

Table 2. Vegetation indices determined by field spectrophotometer (Kompolt, 2017)

\begin{tabular}{|c|c|c|c|c|}
\hline Parameter & Significance & I. treatment & II. treatment & Control \\
\hline NDVI & $* * * 231-\mathrm{aab}$ & $0.824 \pm .0 .01$ & $0.777 \pm 0.037$ & $0.790 \pm 0.012$ \\
\hline TCARI/OSAVI & *** 132-aab & $0.176 \pm 0.023$ & $0.203 \pm 0.005$ & $0.177 \pm 0.05$ \\
\hline RDVI & $* * * 231-a a b$ & $0.552 \pm 0.011$ & $0.513 \pm 0.028$ & $0.521 \pm 0.014$ \\
\hline PRI3 & $* * * 321-\mathrm{abb}$ & $-0.081 \pm 0.013$ & $-0.07 \pm 0.018$ & $-0.052 \pm 0.004$ \\
\hline EVI & $* * * 231-a a b$ & $0.646 \pm 0.02$ & $0.587 \pm 0.039$ & $0.592 \pm 0.03$ \\
\hline ARI & *** 321-aab & $-2.067 \pm-0.703$ & $-3.182 \pm 0.658$ & $-3.167 \pm 0.571$ \\
\hline CRI & $* * * 321-\mathrm{abb}$ & $15.412 \pm 1.31$ & $15.304 \pm 1.742$ & $14.631 \pm 3.77$ \\
\hline SIPI & $* * * 231-a a b$ & $0.866 \pm 0.002$ & $0.845 \pm-0.018$ & $0.847 \pm 0.014$ \\
\hline PWI & $* * * 132-a b b$ & $0.843 \pm-0.015$ & $0.852 \pm-0.006$ & $0.850 \pm 0.01$ \\
\hline SRWI & ***231-aab & $1.439 \pm 0.001$ & $1.381 \pm 0.057$ & $1.382 \pm 0.055$ \\
\hline
\end{tabular}

Note: $a, b, c$ index - Tukey-Test significance groups $(\mathrm{p}<0.05)$; ${ }^{* *}$ ANOVA significance $\mathrm{p}<0.001 ; 1-$ I. with soil bacteria treatment, 2 - II. head+basic fertilizer; 3 - basic fertilizer.

The photochemical reflectance index (PRI) was the highest in I. treatment. The anthocyanin (ARI) in the treatment II., while the carotinoid (CRI) reflectance index was the highest in the soil bacterial parcel. The leaf structure independent pigment index (SIPI) indicating carotenoid/chlorophyll ratio was of outstanding value in I. treatment, which also indicates the state of the plants' stress (Peñuelas et al., 1995). The soil bacterial parcel had also lower water content based on the PWI index, which explains the more stressful situation than the other two 
treatments. The vegetation indices used for autumn wheat similarly to physiological measurements show that the two treatments improve the stress tolerance of the plants.

On the basis of measurements, with soil bacteria treatment is beneficial in yield, while the head fertilizer is slightly lower. The moisture content measured after harvest also confirms the soil bacteria treatment, as $1.6 \%$ less than in the other two treatments (Figure 2).

Figure 2. Autumn wheat harvest characteristics (Kompolt, 2017)

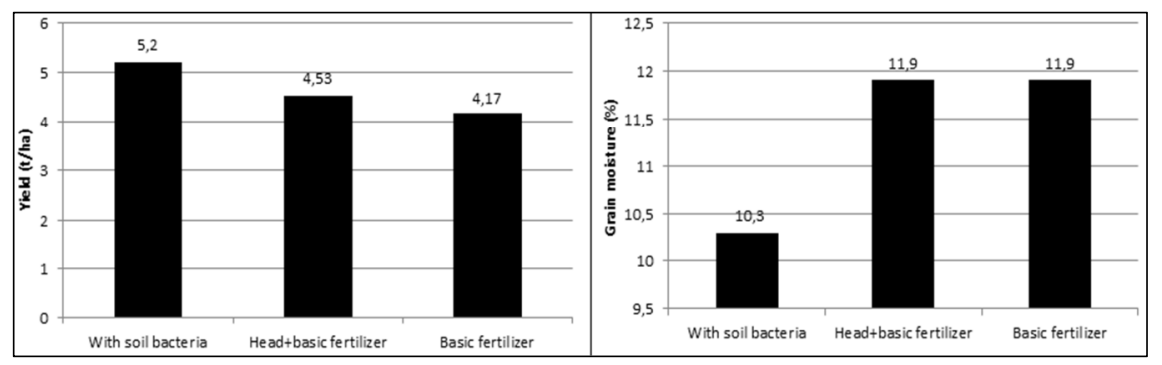

The aerial photographs show the heterogeneity of plots (Figure 3). On the parcels are scattered spots visible. The soil bacterium treated seems homogeneous unlike the other two parcels.

The soil bacteria treatment presumably provided more balanced nutrient and water supply to crops, increased the parcel homogeneity, which is important for crop safety.

In table K7 soil samples were taken at 20 and $40 \mathrm{~cm}$ deep from the three parcels. According to our results (Table 3) In the $20 \mathrm{~cm}$ soil depth the soil moisture content was the lowest in the head fertilizer treatment and the dry matter content the highest. The same could be detected at a depth of $40 \mathrm{~cm}$, too. The $\mathrm{pH}$ was the lowest in the soil bacteria treatment parcel. Based on Gold's binding a sample taken from the ground $20 \mathrm{~cm}$ deep showed the low value of the head fertilized treatment, but in the 40 $\mathrm{cm}$ depth sample it was already the same as the.

According to the results of Table $4.20 \mathrm{~cm}$ in soil depth nitrate at head fertilizer treatment, nitrite, phosphorus at the control, potassium, calcium, magnesium, selenium, iron and lead in the soil bacteria treatment was the highest. At $40 \mathrm{~cm}$ depth nitrate, phosphorus, potassium at control, nitrite, calcium, magnesium, iron and lead at the head fertilizer treatment, selenium at soil bacteria treatment was high.

The nutrient values from stored grain yields showed high value at the control phosphorus, calcium, magnesium, iron, selenium, while in case of soil bacteria treatment they exhibited high sodium values. The head fertilizer treatment showed the values between the two treatments, alone, 
the potassium content was outstanding. It can be concluded that control grain extracted most nutrients from the soil (Table 5).

Figure 3. The NDVI index with the multispectral camera on the three parcels (Kompolt, 2017)

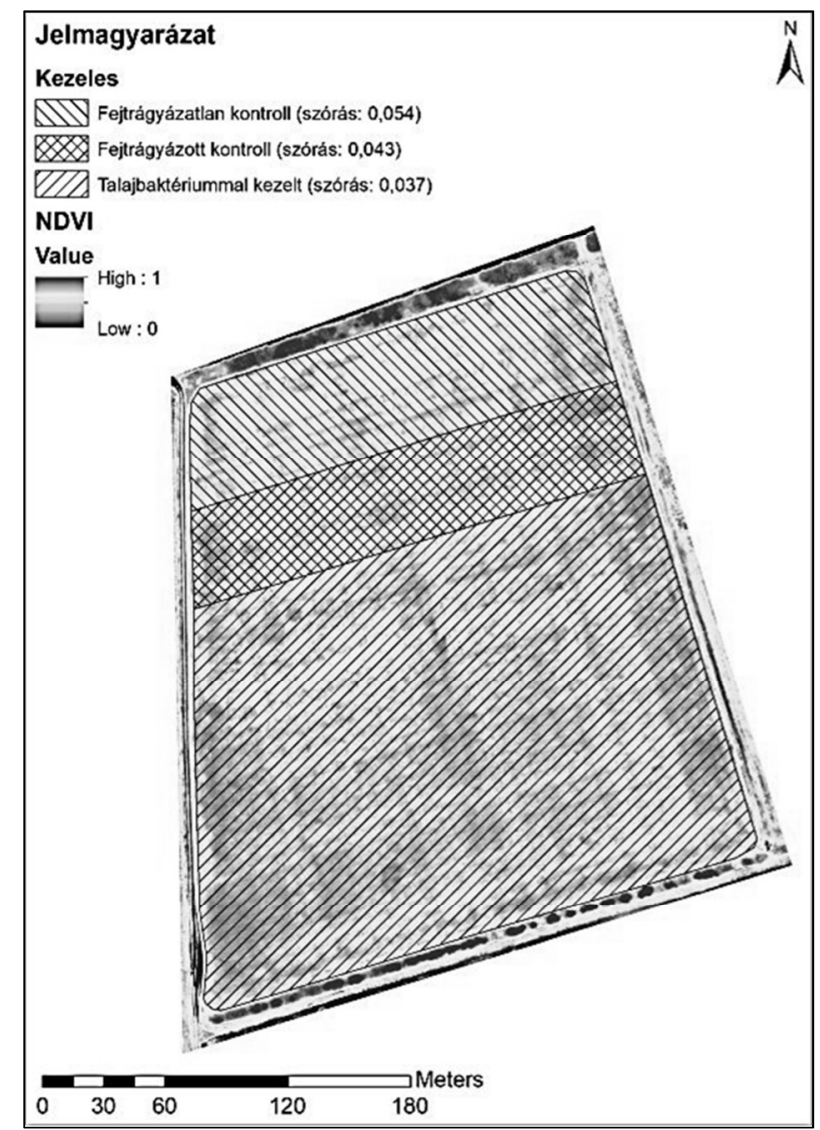

Table 3. Characteristics of soil properties (Kompolt, 2017)

\begin{tabular}{llcccccc}
\hline $\begin{array}{c}\text { Depth } \\
(\mathrm{cm})\end{array}$ & Treatment & $\begin{array}{c}\text { Moisture } \\
\text { content \% }\end{array}$ & $\begin{array}{c}\text { Dry matter } \\
\text { content \% }\end{array}$ & $\begin{array}{c}\mathrm{pH} \\
(\mathrm{KCl})\end{array}$ & $\begin{array}{c}\text { Conductivity } \\
\mathrm{S} \mathrm{m}^{-1}\end{array}$ & $\begin{array}{c}\text { Soluble } \\
\text { salt in } \\
\text { water \% } \\
(\mathrm{m} / \mathrm{m})\end{array}$ & $\begin{array}{c}\text { Gold's } \\
\text { binding }\end{array}$ \\
\hline 20 & Control & 22.10 & 77.90 & 4.71 & 335 & 0.04 & 45 \\
40 & Control & 20.10 & 79.90 & 4.68 & 464 & 0.05 & 47 \\
20 & I. treatment & 19.45 & 80.55 & 4.70 & 304 & 0.03 & 42 \\
40 & I. treatment & 18.20 & 81.80 & 4.70 & 351 & 0.04 & 47 \\
20 & II. treatment & 21.63 & 78.37 & 4.57 & 372 & 0.04 & 45 \\
40 & II. treatment & 20.81 & 79.19 & 4.52 & 325 & 0.03 & 44 \\
\hline
\end{tabular}


Table 4. The nutrients content values of soil samples of different depths ( $\left.m g \mathrm{~kg}^{-1}\right)$ (Kompolt, 2017)

\begin{tabular}{llcrrrrrrrr}
\hline $\begin{array}{c}\text { Depth } \\
(\mathrm{cm})\end{array}$ & Treatment & $\mathrm{P}$ & $\mathrm{K}$ & $\mathrm{Ca}$ & $\mathrm{NO}_{3}-\mathrm{N} \mathrm{NO}_{2}-\mathrm{N}$ & $\mathrm{Mg}$ & $\mathrm{Se}$ & $\mathrm{Pb}$ & $\mathrm{Fe}$ \\
\hline 20 & Control & 49118 & 9687 & 4606 & 24.2 & 0.04 & 5469 & 24.8 & 19.1 & 16733 \\
40 & Control & 48935 & 9655 & 3053 & 9.9 & 0.02 & 5270 & 23.6 & 17.0 & 16066 \\
20 & I. treatment & 47290 & 8960 & 4629 & 26.6 & 0.02 & 5285 & 24.6 & 19.0 & 16457 \\
40 & I. treatment & 41642 & 8641 & 5500 & 0.9 & 0.04 & 6578 & 37.3 & 21.7 & 29196 \\
20 & II. treatment & 46436 & 10115 & 5116 & 7.2 & 0.03 & 5612 & 25.7 & 19.9 & 28857 \\
40 & II. treatment & 44184 & 9134 & 5223 & 2.5 & 0.03 & 5996 & 40.4 & 19.7 & 29112 \\
\hline
\end{tabular}

Table 5. Values of nutrient content of stored grain yield (Kompolt, 2017)

\begin{tabular}{lcccccccc}
\hline \multicolumn{1}{c}{ Treatment } & $\mathrm{P}$ & $\mathrm{K}$ & $\mathrm{Na}$ & $\mathrm{Ca}$ & $\mathrm{Mg}$ & $\mathrm{Fe}$ & $\mathrm{Se}$ & $\mathrm{Pb}$ \\
\hline Control & 2596 & 4438 & 258 & 1077 & 1502 & 51 & 6.2 & 0.9 \\
I. treatment & 2341 & 4440 & 282 & 903 & 1288 & 45 & 4.3 & 1.1 \\
II. treatment & 2175 & 4110 & 306 & 930 & 1233 & 41 & 3.5 & 1.2 \\
\hline
\end{tabular}

\section{Conclusions}

The leaves of healthy, nearly the same size and color plants were measured, therefore measurements are not subjective. Presumably, under optimum conditions, the yield-enhancing effect is expected in the proportions of the experiment results. On aerial photographs, it is clear that parcels are heterogeneous, the most the control. Based on the results, the soil bacteria treatment can be recommended in public production, for which physiological processes were more intense, the ripening occurred sooner, and the moisture content at harvest was $1.6 \%$ lower on the soil bacteria than on the other two treatments When evaluating soil samples, the head fertilization resulted the soil to have a lower moisture content but higher dry matter content. At depths of $20 \mathrm{~cm}$ on the soil bacteria treatment was measured low nitrate, phosphorus, but high potassium values. In the depths of $40 \mathrm{~cm}$, the result was high selenium and iron content. In the case of the grain yield, were also lower phosphorus, potassium, calcium, magnesium, iron and selenium value than on the other two treatments. The soil bacteria treatment has a beneficial effect on soil $\mathrm{pH}$ reduction, deeper soil level in moisture conservation and nutrient utilization.

\section{Acknowledgments}

Our work is supported by EFOP 3-6-1-16-2016-00001 "Complex development of research capacities and services at the Eszterházy Károly University" project. 


\section{References}

Dilci, B. (2008): Ph.D. degree. Institut für Pfl anzenbau und Bodenkunde. Agronomic approaches in yield and quality stability of high oleic sunfl owers (Helianthus annuus L.) Julius Kühn-lnstitut. Bundesforschungsinstitut für Kulturpflanzen. Quedlinburg. Deutschland. Göttingen.

Gamon, J. A.-Peñuelas, J.-Field, C. B. (1992): A narrow-waveband spectral index that tracks diurnal changes in photosynthetic fficiency. Remote Sensing of Environment. 41: 35-44.

Genty, B.-Briantais, J. M.-Baker N. R. (1989): The relationship between the quantum yield of photosynthetic electron transport and quenching of chlorophyll fluorescence. Biochim. Biophys. Acta. 990: 87-92.

Gitelson, A. A.-Merzlyak M. N.-Chivkunova, O. B. (2001): Optical properties and nondestructive estimation of anthocyanin content in plant leaves. Photochem. Photobiol. 74: 38-45.

Gitelson, A. A.-Zur, Y.-Chivkunova, O. B.-Merzlyak, M. N. (2002): Assessing carotenoid content in plant leaves with reflectance spectroscopy. Photochem. Photobiol. 75: 272-281.

Hawkins, T. S.-Gardiner, E. S.-Comer, G. S. (2009): Modeling the relationship between extractable chlorophyll and SPAD-502 readings for endangered plant species research. J. Nat. Conserv. 17: 123-127.

Herczeg B. (szerk.) (2013): Üzemi gyakorlatok munkanaplója. Károly Róbert Főiskola. Gyöngyös. 68-80.

Holló S.-Kádár I. (2003): A mútrágyázás és a meszezés hatása a talaj termékenységére. [In: Blaskó L.-Zsigrai Gy. (szerk.) Mútrágyázás, talajsavanyodás és meszezés összefüggései az OMTK kísérlethálózat talajain (Karcag-Keszthely).] Kompolt. 217-224.

Holló S.-Pethes J.-Ambrus A. (2009): A tartós szerves- és mútrágyázás hatása a talaj könnyen oldható foszfortartalmára Kompolton, csernozjom barna erdótalajon. Tartamkísérletek jelentősége a növénytermesztés fejlesztésében. Jubileumi tudományos konferencia. Martonvásár, 2009. október 15. 227-234.

Holló S.-Pethes J.-Ambrus A. (2009): A talaj könnyen oldható foszfortartalmának változása tartamkísérletekben, Kompolton. Tartamkísérletek jelentősége a növénytermesztés fejlesztésében. Jubileumi tudományos konferencia. Martonvásár, 2009. október 15. 235-240.

Huete, A.-Didan, K.-Miura, T.-Rodriguez, E. P.-Gao, X.-Ferreira, L. G. (2002): Overview of the radiometric and biophysical performance of the MODIS vegetation indices. Remote Sens. Environ. 83: 195-213.

Kátai J. (2011): Talajökológia. Debreceni Egyetem - Nyugat-Magyarországi Egyetem - Pannon Egyetem.

Markwell, J.-Osterman, J.-Mitchell, J. (1995): Calibration of the Minolta SPAD-502 leaf chlorophyll meter. Photosynth. Res. 46: 467-472.

Net1: www.fao.org (letöltés dátuma: 2018. 02. 21.)

Net2: www.ksh.hu (letöltés dátuma: 2018. 02. 20.)

Net3: Bio-Nat Kft. http:/ / www.mikro-vital.hu/ (letöltés dátuma: 2018. 01. 20.)

Net4: www.hetilap.karpatinfo.net/hetilap/gazdasag/mi-mikro-vital bakterium tragya (letöltés dátuma: 2018. 01. 18.) 
Net5: https://www.agronaplo.hu/szakfolyoirat/2017/02/pr/mikro-vital bakteriumtragya (letöltés dátuma: 2018. 01. 15.)

Net6: agraragazat.hu/cikk/bakteriumtragyak-szakszeru-kijuttatasa (letöltés dátuma: 2018. 01. 20.)

Net7: MiniPAM Manual http:/ /ictinternational.com/content/uploads/2014/ 05/MINI_PAM_II_Manual.pdf (letöltés dátuma: 2018.03.26.)

Peñuelas, J.-Filella, I.-Lloret, P.-Muñoz, F.-Vilajeliu, M. (1995): Reflectance assessment of mite effects on apple trees. International Journal of Remote Sensing. 16-14: 2727-2733.

Peñuelas, J.-Piñol, J.-Ogaya, R.-Filella, I. (1997): Estimation of plant water concentration by the reflectance Water Index $\left(\mathrm{R}_{900} / \mathrm{R}_{970}\right)$. Int. J. Remote Sens. 18: 2869-2875.

Rondeaux, G.-Steven, M.-Baret, F. (1996): Optimization of soil-adjusted vegetation indices. Remote Sensing of Environment. 55: 95-107.

Rougean, J. L.-Breon, F. M. (1995): Estimating PAR absorbed by vegetation from bidirectional reflectance measurements. Remote Sensing of Environment. 51: 375-384.

Rouse, J. W.-Haas, R. H.-Schell, J. A.-Deering, D. W.-Harlan, J. C. (1974): Monitoring the vernal advancements and retrogradation of natural vegetation. NASA/GSFC final report. MD. USA. Greenbelt. 371.

Schreiber, U.-Klimant, I.-Kühl, M.-Reising, H. (1996): Measurement of chlorophyll fluorescence within leaves using a modified PAM Fluorometer with a fiberoptic microprobe. Res. 47. 1: 103-109.

Spinetti, C.-Mazzarini, F.-Casacchia, R.-Colini, L.-Neri, M.-Behncke, B.-Salvatori, R.Fabrizia, B.-Pareschi, M. (2009): Spectral properties of volcanic materials from hyperspectral field and satellite data compared with LiDAR data at Mt. Etna. International Journal of Applied Earth Observation and Geoinformation. 11: 142-155.

Szabados, Gy. (2008): Power for soil - Sustainability for earth, how an invisible microorganism can help to develop the ecomarketing attitude. [In: Fojtik, J. (ed.) Proceedings and Abstracts of the International Innovation Conference for Co-operation Development (InCoDe).] October 16-18, 2008. University of Pécs Faculty of Business and Economics. Misprint Kft. Pécs. 304-310.

Zarco-Tejada, P.-Rueda, C.-Ustin, S. (2003): Water Content estimation in vegetation with MODIS reflectance data and model inversion methods. Remote Sens. Env. 85. 1: 109-124. 